УДК 373.3:51.376.8

DOI https://doi.org/10.26661/2522-4360-2021-2-13

\title{
ФОРМУВАННЯ УМІНЬ РОЗВ'ЯЗУВАТИ СЮЖЕТНІ ЗАДАЧІ В УЧНІВ ПОЧАТКОВИХ КЛАСІВ ІЗ ДИСЛЕКСІЄЮ
}

\author{
Расвська I. М. \\ кандидат педагогічних наук, \\ доцент кафедри теорії та методики дошкільної та початкової освіти \\ Херсонський державний університет \\ вул. Університетська, 27, Херсон, Україна \\ orcid.org/0000-0002-4582-2839 \\ rayevsk@ukr.net
}

Кабельнікова Н. В.

кандидат педагогічних наук, дочент, доиент кафедри спеиіальної освіти

Херсонський державний університет

вулиия Університетська, 27, Херсон, Україна

orcid.org/0000-0002-5236-2033

nataliavm09@gmail.com

\begin{abstract}
Ключові слова: специифічні труднощі навчання, молодші школярі з порушеннями читання, математична компетентність учнів початкових класів із дислексією, математичні задачі, методи та прийоми формування умінь розв'язування сюжетних задач в учнів із дислексією.
\end{abstract}

Стаття присвячена проблемі формування умінь розв'язувати сюжетні задачі в учнів початкових класів із дислексією. Наголошується, що сутність діяльності 3 розв'язування задач полягає у перетворенні учнем словесно заданого сюжету, що містить числові компоненти і характерну структуру, на мову арифметичного запису як перехід від словесної моделі до моделі математичної або схематичної. В основі здійснення цього переходу лежить аналіз тексту і виділення в ньому математичних понять і співвідношень. Вміння розв'язувати сюжетні задачі сприяють розвитку внутрішньої мотивації, інтересу до навчальної діяльності, виробленню в учнів спеціальних умінь та навичок; допомагають дітям засвоїти математичні поняття й закономірності, формують здатність до планування та самоконтролю Учні з труднощами у навчанні, у тому числі з дислексією, не здатні без застосування спеціальної педагогічної допомоги опанувати уміннями та навичками розв'язування задач. Авторами розкрито психофізіологічні механізми виникнення труднощів опанування навичками читання (дислексіі) у молодших школярів, висвітлено їх вплив на формування математичної компетентності. Проаналізовано помилки, які виникають у дітей із дислексією під час розв'язування сюжетних задач, особливості сприйняття тексту задач та виконання арифметичних дій під час їх розв'язування. Визначено перспективні підходи, спрямовані на інтенсифікацію процесу навчання учнів із дислексією математики, особливу увагу зосереджено на особливостях використання загальнодидактичних та спеціальних методів та прийомів роботи вчителя початкових класів над сюжетними задачами, що передбачає тісний взаємозв'язок із корекційнорозвитковим логопедичним впливом. Специфіка освітнього процесу для дітей із дислексією полягає у використанні різних рівнів адаптації навчального матеріалу до пізнавальних можливостей та психофізіологічних особливостей учнів із дислексією. Врахування результатів дослідження може стати основою для створення нових навчальних технологій, які передбачають максимальну активізацію більш розвинутих ланок пізнавальної діяльності учнів із дислексією, сприяти профілактиці виникненню у них труднощів під час розв'язування сюжетних задач. 


\title{
FORMING OF SKILLS TO SOLVE THE NARRATIVE TASKS OF PRIMARY SCHOOL PUPILS WITH A DYSLEXIA
}

\author{
Raevska I. M. \\ Candidate of Pedagogical Sciences, \\ Associate Professor at the Department of Theory and Methods of Preschool and Primary Education \\ Kherson State University \\ University str., 27, Kherson, Ukraine \\ orcid.org/0000-0002-4582-2839 \\ rayevsk@ukr.net
}

\author{
Kabelnikova N. V. \\ Candidate of Pedagogical Sciences \\ Associate Professor at the Department of Special Education \\ Kherson State University \\ University str., 27, Kherson, Ukraine \\ orcid.org/0000-0002-5236-2033 \\ nataliavm09@gmail.com
}

\begin{abstract}
Key words: special difficulties of studying, young pupils with breaking of reading, mathematical competence of primary classes pupils with a dyslexia, mathematical tasks, methods and skills of a formation of skills of the solving the narrative tasks of pupils with a dyslexia.
\end{abstract}

The article is dedicated to the problem of the formation of skills to solve the narrative tasks of primary school pupils with a dyslexia. It is stressed that the essence of the activity on the solving of tasks is in the transformation by pupil in words the given plot which has the figure components and the character structure, on the language of the arithmetic recording as a crossing from the verbal model to the mathematical model or scheme. At the heart of this crossing there is a text analysis and the selection in it of the mathematical notions and the correlations. The skills of solving the narrative tasks make an influence on the development of the internal motivation, an interest to the studying activity, creating of the special skills of pupils, help to children to master the mathematical notions and the regularities, form the ability to the planning and the self-control. The pupils with the difficulties in the studying and with a dyslexia as well can't without the application of a special pedagogical assistance to get the skills to solve the tasks. The authors opened the psychical and physiological mechanisms of the mastering of difficulties to master the skills of the reading (dyslexia) of the young pupils, it is reflected its impact on the forming of the mathematical competence. It is analyzed the mistakes which appear in children with dyslexia during the solving of the narrative tasks, the peculiarities of the text perception, tasks and the doing of the arithmetic actions during its solving. It is defined the perspective approaches directed on the intensification of the process of pupils' studying with a dyslexia of mathematics, a special attention is concentrated on the peculiarities of a usage of the general didactic and special methods and skills of a work of a teacher of primary school under the narrative tasks which presuppose the connection with the correction and development speech therapy impact. The peculiarity of the educational process for the children with a dyslexia is in the usage of the different levels of the adaptation of the studying material to the cognitive possibilities and psychological and physiological peculiarities of pupils with a dyslexia. An acconting of the results of the investigation can become the background for the creation of new studying technologies which presuppose the maximum activation of more developed branches of the cognitive activity of pupils with a dyslexia, influence on the prophylaxis of the appearing the difficulties during the solving of the narrative tasks. 
Реформування освітньої політики в Україні передбачає зміни не тільки у змісті освіти, а й у функціонуванні освітніх закладів, що окреслені у «Національній доктрині розвитку освіти в Україні у XXI столітті», яку спрямовано на «особистісну орієнтацію освіти; створення рівних можливостей для дітей та молоді у здобутті якісної освіти; забезпечення варіативності здобуття базової або повної загальної середньої освіти відповідно до здібностей та індивідуальних можливостей» [3], а також у Законах України «Про освіту», «Про внесення змін до Закону України «Про освіту» щодо особливостей доступу осіб з особливими освітніми потребами до освітніх послуг».

Серед усіх дітей 3 особливими освітніми потребами значну частину становлять учні зі специфічними труднощами навчання (дискалькулією, дисграфією, дислексією), пов'язаними 3 порушеннями навчально-пізнавальної діяльності (Т. Ахутіна, Ю. Коломієць, І. Мартиненко, Ю. Мікадзе, А. Семенович тощо). У зазначеної категорії школярів на фоні збереженого інтелекту виникають значні труднощі в опануванні базовими академічними знаннями та функціональними уміннями й навичками, зокрема математичними операціями та писемним мовленням [1, с. 13].

Дислексія як один із типів специфічних труднощів у навчанні являє собою стан, що характеризується стійкою нездатністю опанувати навичками читання дітьми зі збереженими аналізаторами (слуховим, зоровим), збереженим інтелектом, достатнім рівнем розвитку мовлення, а також зумовлює застосування педагогічно правильної методики навчання читання [2, с. 42].

За дослідженнями науковців, дислексія виявляється у дітей вже на початкових етапах навчання читання у вигляді труднощів опанування звуко-буквенним позначенням, цілісними прийомами читання, нерозуміння прочитаного тексту за сформованої технічної сторони читання, аграматизмами під час читання тощо. Все це негативно позначається на шкільній успішності [2, с. 18]. Аналіз літературних джерел (О. Даніч, К. Єфремов, О. Іншакова, О. Корнєв, Ю. Костенкова, Р. Лалаєва, А. Огаркіна, Ю. Савостьянова, Н. Ципіна та ін.) засвідчив, що більшість досліджень науковців розкривають особливості опанування учнями початкових класів зі специфічними порушеннями читання мовно-літературної освітньої галузі, водночас недостатньо представлено імперичний та теоретичний матеріали щодо впливу дислексії на засвоєння математичної компетентності, зокрема на здатність зазначеної категорії школярів розв'язувати сюжетні задачі. Вчителі початкової школи під час навчання зазначеної категорії учнів змушені адаптувати методики для закладів загальної освіти. Цей шлях є недостатньо ефективним, оскільки педагоги недостатньо обізнані щодо психофізіологічних причин, механізмів та особливості розвитку молодших школярів Із дислексією. Натомість застосування спеціальних методів та прийомів під час формування умінь розв'язувати сюжетні задачі в учнів зі специфічними порушеннями читання не лише сприяло б засвоєнню цими дітьми програмного матеріалу 3 математики, а й вирішувало б завдання корекції пізнавальної, навчальної та практичної діяльності, розвитку довільної уваги, розумових операцій, мовлення і становленню особистості загалом.

Метою статті $\epsilon$ визначення та опис методів i прийомів формування умінь розв'язувати сюжетні задачі учнями початкових класів із дислексією 3 урахуванням особливостей проявів порушення та труднощів, яких зазнає зазначена категорія дітей під час опанування програмним матеріалом 3 математики.

Методика навчання учнів розв'язувати сюжетні задачі є складним процесом розумової діяльності, спрямованим на перетворення об'єкта, що описаний у змісті задачі, на вирішення суперечності між умовою та запитанням задачі. Сутність діяльності з розв'язування задач полягає у знаходженні такої теорії, такої системи загальних положень, застосовуючи які до умов задачі і проміжних результатів розв'язування, можна врешті відповісти на запитання задачі (задовольнити запитання задачі) або у відшукуванні способу іiї розв'язування [4, с. 53]. Це процес перетворення учнем словесно заданого сюжету, що містить числові компоненти і характерну структуру, на мову арифметичного запису як перехід від словесної моделі до моделі математичної або схематичної. В основі здійснення цього переходу лежить аналіз тексту і виділення в ньому математичних понять і співвідношень. Навчити учнів із дислексією розв'язувати сюжетні задачі $\epsilon$ одним із головних завдань у вивченні математики на початкових етапах навчання у закладі загальної середньої освіти. Сюжетні задачі є важливим засобом у формуванні внутрішньої мотивації, інтересу до навчальної діяльності, розвитку логічного мислення, дозволяють виробити в учнів із порушеннями читання спеціальних умінь та навичок. Також під час розв'язування сюжетних задач молодші школярі з дислексією засвоюють математичні поняття і закономірності, вчаться планувати свою діяльність та здійснювати самоконтроль.

С. Скворцова під умінням розв'язувати сюжетні задачі розуміє складне вміння, яке містить комплекс умінь нижчого порядку, що стосуються послідовно виконуваних дій, починаючи з уміння аналізувати текст задачі й завершуючи вмінням перевіряти правильність розв'язання [5, с. 43].

Отже, у процесі навчання розв'язання сюжетних задач умовно можна виділити два 
взаємопов'язаних етапи: ознайомлення зі структурою задачі, способами іiі розв'язання та навчання прийомів обчислень і перевірки правильності розв'язання.

Перший етап процесу навчання розв'язання сюжетних задач будемо розглядати 3 погляду організації навчальної діяльності. Умова задачі $\epsilon$ одним із видів практичних завдань, вирішення якої підпорядковується певному плану. Для реалізації плану учень виконує низку навчальних дій, які в свою чергу мають складний операційний склад: 1) читання умови задачі передбачає інтонаційне виділення смислових, логічно закінчених частин; 2) здійснення короткого запису умови задачі або зображення за допомогою малюнка, схеми, таблиці, тобто переклад в іншу знакову систему за певними правилами (модель задачі); 3) визначення послідовності арифметичних дій, складових частин рішення задачі й здійснення вибору дії, яка відображає зв'язки між даними і шуканими; 4) перевірка правильності виконаної роботи. Таким чином, процес рішення задачі дозволяє дитині усвідомити мету діяльності (вирішити задачу), реалізувати цю мету з допомогою системи дій, здійснити контроль (чи досягнута мета), оцінити правильність виконуваних дій.

Результати проведеного нами експериментального дослідження труднощів, які виникають в учнів 3-4-х класів із дислексією під час розв'язування сюжетних задач, засвідчили таке:

1. Під час ознайомлення з умовою задачі $29,2 \%$ школярів недостатньо усвідомлюють предметну ситуацію, викладену в ній, їм недоступні взаємовідношення між числовими даними, наслідком чого є виконання формальних дій із числовими даними; 31,7\% дітей сприймають умову задачі фрагментарно, окремими частинами, внаслідок чого діти не можуть встановити зв'язок між даними і шуканим, обирають дії на основі або сприйнятої частини, або окремих фраз, не звертаючи увагу на головне запитання задачі. Натомість 39,1\% молодших школярів із дислексією здатні лише до неповного і поверхового аналізу змісту задачі, що призводить до невідповідності між розумінням самої задачі і способом їі розв'язування.

2. Під час розв’ язування сюжетної задачі $36,4 \%$ учнів із порушеннями читання, не зрозумівши предметного змісту задачі, керуються не суттєвими ознаками, окремими словами, а використовують лише наявні числа, які чітко видно в умові, i не помічають проміжних числових даних, що містяться у задачі. Особливо яскраво це виявляється у процесі розв'язування задач на збільшення або зменшення числа на кілька одиниць.

Для 63,6\% учнів із дислексією порушення розуміння предметного змісту задачі пов’язано з тим, що в них смислове навантаження припадає на прийменники, прислівники, займенники, оперування якими у дітей зі специфічними порушеннями читання $є$ вкрай утрудненим. Математичні залежності між двома даними передаються, головним чином, за допомогою прийменника «на» і слів «більше», «менше», «було», «стало», школярі неусвідомлено вибирають їх як основу для розв'язання.

3. Труднощі наочного уявлення словесно оформленої задачі виявлено у 87,8\% учнів початкових класів із дислексією. Натомість помилки під час розв'язування задач предметно-практичного характеру допускають лише $11,7 \%$ зазначеної категорії дітей. Утруднення під час розв'язуванні задачі, оформленої у словесно-числовому вираженні, пояснюються, з одного боку, недостатньою здатністю школярів із дислексією сприймати мовленнєвий матеріал в акустичній модальності, а з іншого - неправильним усвідомленням деяких слів, словосполучень, які несуть у собі логічне (математичне) навантаження.

Таким чином, більшості помилок під час розв'язування сюжетних задач учні початкових класів із дисграфією припускаються під час:

- ознайомлення зі змістом задачі;

- аналізу задачі;

- пошуку способу розв'язання (неправильний вибір арифметичної діï);

- обрахунку результату задачі;

- виконаня обчислень з іменованими числами;

- формування і запису відповіді задачі.

Зазначені труднощі однаково спостерігаються в учнів із дислексією як 3-х класів, так і 4-х, що доводить первинне порушення у них психофізіологічних механізмів мовленнєвої діяльності щодо несформованості загальнонавчальних умінь та навичок.

3 огляду на зазначене, для підвищення ефективності у формуванні математичної компетентності, зокрема у виробленні в учнів початкових класів із дислексією умінь розв'язувати сюжетні задачі, необхідно вдосконалювати педагогічні методи та прийоми навчання. Слід наголосити також на доцільності поєднання корекційно-розвиткового логопедичного впливу та роботи вчителя із зазначеною категорією учнів.

Навчити дитину 3 дислексією розв'язувати сюжетні задачі - це означає сформувати у неї вміння встановлювати взаємозв'язок між даними і шуканими, намітити шляхи для правильної відповіді на головне питання.

Для вирішення проблеми висуваються певні вимоги:

- матеріал має відповідати рівню арифметичної підготовки учнів, а також їхнім віковим та психофізіологічним особливостям; 
- умова задачі повинна бути сформульована чітко, ясно, зрозумілою мовою і не містити зайвих елементів, які б розпорошували увагу школярів.

- запитання задачі має формулюватися чітко, лаконічно, коротко і може міститися як у кінці, так і на початку;

- навчити дітей читати умову задачі так, щоб вони зрозуміли математичну термінологію, усвідомили такі поняття, як умова задачі, запитання, відповідь;

- встановлювати зв'язки між числовими даними і шуканим;

- навчити свідомо вибирати арифметичні дії;

- розв'язувати задачі з опорою на малюнок, опорні схеми і короткий запис умови задачі.

Навчаючи учнів 3 дислексією розв'язувати задачі, треба враховувати, що засвоєння необхідного матеріалу не повинно мати характеру механічного заучування й тренування. Знання, одержані учнями, мають бути усвідомленими. Від предметної, наочної основи слід переходити до формування доступних математичних понять, вести учнів до узагальнень і на їх основі виконувати практичні роботи.

На уроках математики в результаті взаємодії зусиль учителя початкових класів та логопеда (за спрямовуючого й організуючого впливу вчителя) розвивають елементарне математичне мислення учнів; формують і коригують такі його форми, як порівняння, аналіз, синтез; розвивають здібності до узагальнення й конкретизації, тим самим створюючи умови для корекції пам'яті, уваги та інших психічних функцій.

Робота над усвідомленням ситуації, яка описується в задачі, встановлення залежностей між числовими даними і шуканим має проводитися учителем у такій послідовності:

1) словникова робота;

2) читання тексту задачі та іiі розбір (аналіз);

3) запис умови задачі (з опорою на наочні схеми);

4) повторення задачі за запитаннями.

Перш ніж розпочати розв'язування задачі, необхідно з'ясувати, чи зрозумілі учням із дислексією слова, які знаходяться у її тексті. Слова в задачах умовно поділяють на 3 групи.

Перша група - це слова, які хоча й передають предметно-дійовий зміст задачі, але не несуть у собі математичного навантаження, а тому спеціально не пояснюються. Це назви предметів, ознак, дій тощо. Вони пояснюються учням за допомогою застосування різних видів наочності перед аналізом і розв'язуванням конкретної задачі.

Другу групу стоановлять слова i лексично нерозривні словосполучення, які означають математичні величини, одиниці вимірювання і виражають відношення залежності між ними: «стільки ж», «більше-менше», «довжина», «сантиметр» та інші. їх необхідно розбирати з учнями. Вони виражають поняття математичного змісту і пов'язані із задачами певного типу. Так, під час вивчення теми «Збільшення та зменшення числа на кілька одиниць» учитель спочатку формує поняття «стільки ж», «більше на...», «менше на...», «збільшити на ...», «зменшити на...», а потім переходить до розв'язування текстових задач, до яких включені вже знайомі мовленнєві форми.

До третьої групи відносяться слова, які не $\epsilon$ ключовими у вираженні математичних відношень, але вони означають реальний стан, дії, послідовність дій тощо, які безпосередньо не впливають на зміни кількісних зв'язків. Це такі слова, як «було», «стало», «залишилось» тощо. Діти повинні пов'язати окремі слова тексту зі знаками арифметичної дії («залишалось - відняти», «разом - додати»).

Своєрідність тексту умови задачі усвідомлюється учнями 3 дислексією краще під час проведення з ними спеціальної роботи. Текст умови задачі спочатку читає або розповідає вчитель, акцентуючи увагу учнів інтонацією, паузою, виділенням голосом на математичні вирази, питання задачі. Вчитель логічним наголосом виділяє ті речення, словосполучення або слова, які прямо вказують на певну дію. Тільки після цього умову задачі читає учень.

Виділяють декілька прийомів, які дають можливість виявити рівень сприймання учнями умови задачі:

- придумати фразу з даним словом;

- вказати на предмет, який позначається даним словом;

- продемонструвати дію, яка б відповідала слову.

Учні мають засвоїти не тільки слова, а й зміст задачі загалом. Цьому сприяють такі прийоми, як: розподіл тексту задачі на основні складові частини, підкреслюючи їх кольоровим олівцем; відокремлення однієї частини тексту від другої невеличкими інтервалами; відокремлення або виділення (кольором) числових даних; виділення задачі в окрему лінію.

Необхідною умовою успішного розв' язування сюжетної задачі $є$ розуміння іiі тексту. До прийомів, що сприяють розумінню тексту задачі учнями 3 дислексією, можна віднести: переказ змісту задачі своїми словами; відповідь на запитання за змістом задачі; розв'язання задачі предметно-дійовим способом, використовуючи для цього ті предмети, про які йдеться в задачі. Ілюстрована форма запису задачі застосовується під час розв'язування задач на конкретний зміст дії множення, кратне порівняння двох чисел, на вміщення, знаходження частини від числа тощо.

Крім ілюстративної, доцільно застосовувати i такі форми запису умови задачі, як скорочена, 
структурна, (скорочено-структурна), графічна, таблична, схематична та повна.

Більш ефективною з погляду доступності розуміння зв' язків між даними і шуканим є структурна (скорочено-структурно) форма запису умови задачі. В ній кожна логічно завершена частина записується 3 нового рядка, а питання пишеться внизу умови або збоку.

Скорочена форма запису передбачає виділення та запис числових даних та тих слів і виразів, що сприяють розумінню сутності задачі. Запитання до задачі записується в кінці у лінію і повністю. Наприклад: «Маринка нанизала на нитку 3 червоні намистинки, а жовтих - на 5 більше. Скільки всього намистинок нанизала Маринка?»

Червоних - 3 штуки

Жовтих - на 5 штук більше

Скільки всього намистинок нанизала Маринка?

Здійснюючи такий запис задачі, учні переходять до складання плану розв'язування задачі, визначають кількість дій, інтерпретуючи їх певним чином.

Розв'язування задачі - це виконання арифметичних дій відповідно до складеного плану. Кожна дія супроводжується їі розв'язанням, яке включає формулювання питання та мотивацію вибору дії. Розбір задачі посідає центральне місце у їі розв' язанні. Для його проведення школярі 3 дислексією мають задіяти такі процеси мислення, як аналіз і синтез.

Отже, у процесі опанування уміннями розв'язувати сюжетні задачі в учнів із дислексією розви- вається активний словник, збагачуючись специфічними математичними термінами й виразами, формуються просторові відношення, виражені у вербальній формі, удосконалюється граматична будова мовлення. Учні вчаться коментувати свою діяльність, давати повний словесний звіт про вирішення задачі, виконання арифметичної дії. Все це вимагає від учнів більше відповідальності та усвідомленості своєї діяльності, їхні дії набувають узагальненого характеру, що, безумовно, має величезне значення для корекції як мовленнєвої, так і пізнавальної сфери дітей. Навчання математики організує й дисциплінує учнів із дислексією, сприяє формуванню у них таких особистісних якостей, як акуратність, наполегливість, здатність до вольового зусилля, виховує звичку до праці, бажання працювати, вміння доводити будь-яку справу до кінця, що сприяє підвищенню шкільної успішності загалом.

Проведене нами дослідження не вичерпує всіх аспектів проблеми навчання учнів початкової школи $з$ дислексією розв'язувати сюжетні задачі. Перспективами подальших наукових пошуків $\epsilon$ розроблення диференційованого підходу на уроках математики до формування умінь розв'язувати задачі в учнів зі специфічними труднощами у навчання 3 використанням різного рівня допомоги, враховуючи первинні порушення психофізіологічних процесів та особливості розвитку загальнонавчальних умінь та навичок.

\section{ЛIТЕРАТУРА}

1. Базима Н.В., Качуровська О.Б., Коломієць Ю.В., Мартиненко І.В. Дитина з труднощами в навчанні в інклюзивному класі: Навчально-методичний посібник. К.: ДІА, 2019. 148 с.

2. Корнев А.Н. Нарушения чтения и письма у детей: Учебно-методическое пособие. СПб.: ИД «МиМ», 1997. $286 \mathrm{c}$.

3. Національна стратегія розвитку освіти в Україні на період до 2021 року URL: https://zakon.rada.gov.ua/laws/show/344/2013\#Техt (дата звернення 3.08.2021.).

4. Скворцова С.О. Методична система навчання розв'язування сюжетних задач учнів початкових класів: монографія. Одеса: Астропринт, 2006. 349 с.

5. Скворцова С.О. Методика навчання розв'язування сюжетних задач у початковій школі : навчально-методичний посібник для студентів. Частина I. Одеса : «Абрикос-Компани», 2011. 268 с.

\section{REFERENCES}

1. Bazyma, N.V., Kachurovska, O.B., Kolomiiets, Yu.V., Martynenko, I.V. (2-19). Dytyna z trudnoshchamy $\mathrm{v}$ navchanni v inkliuzyvnomu klasi: Navchalno-metodychnyi posibnyk. K.: DIA [in Ukrainian].

2. Kornev, A.N. (1997). Narushenyia chtenyia y pysma u detei: Uchebno-metodycheskoe posobye. SPb.: $\mathrm{YD}$ «MyM» [in Russian]

3. Natsionalna stratehiia rozvytku osvity v Ukraini na period do 2021 roku URL: https://zakon.rada.gov.ua/ laws/show/344/2013\#Text (data zvernennia 3.08.2021.).

4. Skvortsova, S.O. (2006) Metodychna systema navchannia rozviazuvannia siuzhetnykh zadach uchniv pochatkovykh klasiv: monohrafiia. Odesa: Astroprynt, [in Ukrainian].

5. Skvortsova, S.O. (2011) Metodyka navchannia rozviazuvannia siuzhetnykh zadach u pochatkovii shkoli : navchalno-metodychnyi posibnyk dlia studentiv. Chastyna I. Odesa : «Abrykos-Kompany» [in Ukrainian]. 